Between Marxism

and Anarchism 


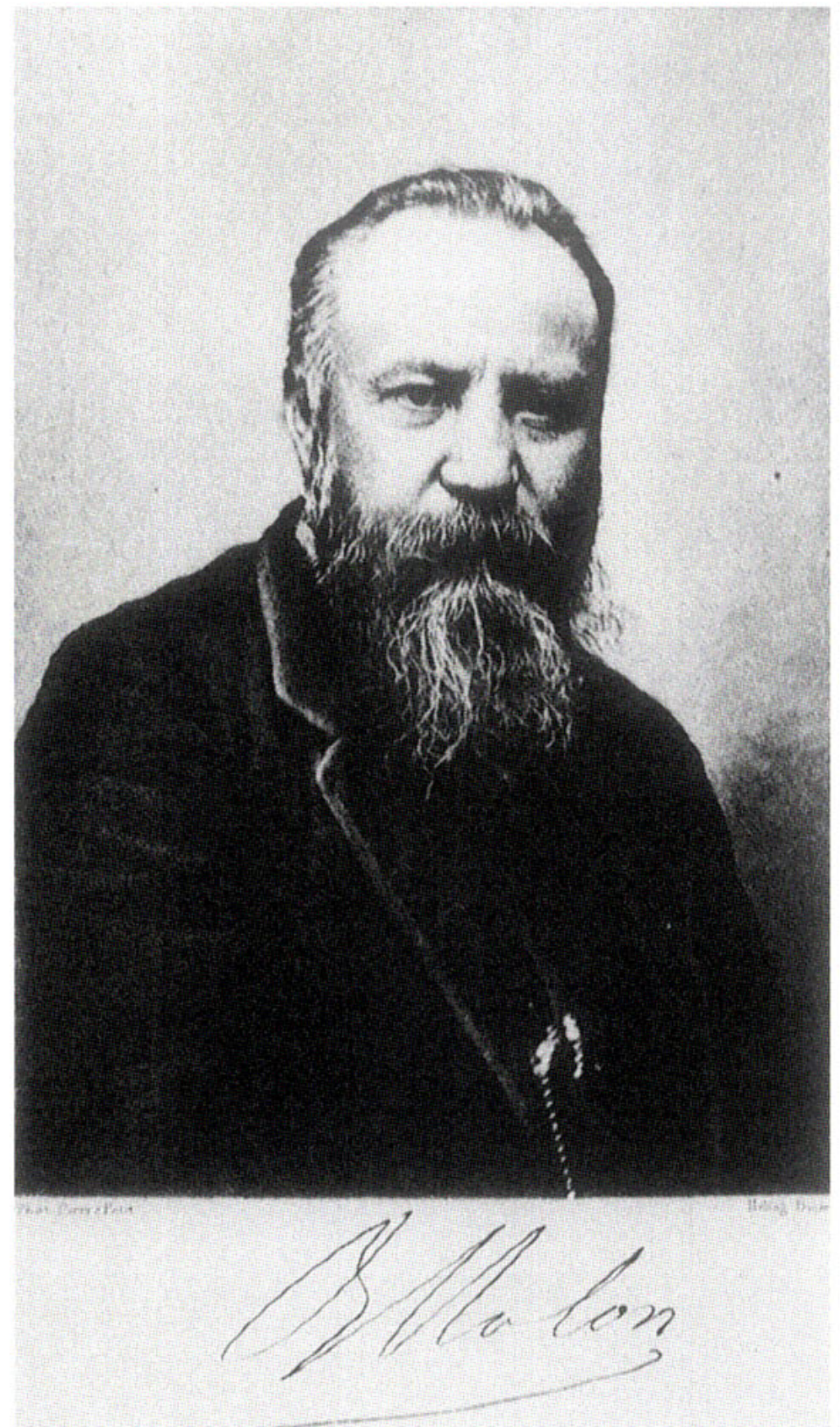




\section{Between Marxism and Anarchism}

Benoît Malon

and French

Reformist Socialism

\section{K. Steven Vincent}

UNIVERSITY OF CALIFORNIA PRESS

Berkeley · Los Angeles · Oxford 
This book is a print-on-demand volume. It is manufactured using toner in place of ink. Type and images may be less sharp than the same material seen in traditionally printed University of California Press editions.

University of California Press

Berkeley and Los Angeles, California

University of California Press, Ltd.

Oxford, England

(1)1992 by

The Regents of the University of California

Frontispiece: Benoît Malon, c. 1890. Photo by Pierre Petit. Originally published in volume 1 of the second edition of Le Socialisme intégral (Paris: Alcan, 1893).

\section{Library of Congress Cataloging-in-Publication Data}

\section{Vincent, K. Steven.}

Between Marxism and Anarchism : Benoît Malon and French reformist socialism / K. Steven Vincent.

p. $\mathrm{cm}$. Includes bibliographical references and index.

ISBN 0-520-07460-2

1. Malon, Benoît, 1841-1893. 2. Socialists-France-Biography. 3. Socialism-France-History-19th century. I. Title. HX264.7.M34V56 1992 335'.0092-dc20

[B]

Printed in the United States of America

The paper used in this publication meets the minimum requirements of American National Standard for Information SciencesPermanence of Paper for Printed Library Materials, ANSI Z39.48-1984. @ 
For Sue 
